Research, part of a Special Feature on Resilience and Change in Arctic Alaska

\title{
A decision support tool for assessing cumulative effects on an Arctic migratory tundra caribou population
}

\author{
Don Russell $^{1,2}$, Anne Gunn ${ }^{2}$ and Robert White ${ }^{2,3}$
}

\begin{abstract}
As large migratory caribou herds decline globally and regional climate trends point to a warmer future, there is a need and a legislative requirement to ensure impacts of industrial development are fully assessed, particularly with respect to cumulative effects. In this paper we use a current proposal, the potential leasing of the 1002 lands on the Alaskan Arctic coastal plain of the Arctic National Wildlife Refuge for hydrocarbon development, to project the potential cumulative effects on the international Porcupine Caribou Herd. Using the caribou cumulative effects model, an existing decision support tool, we evaluate six alternative development scenarios for the 1002 lands, ranging from no leasing to full leasing with standard mitigation conditions. Compared to the no leasing option, at the current population size $(218,000$ caribou), our analysis projected that the likelihood of a herd decline over a 10 -year period would increase from $3 \%$ to $19 \%$ depending on the leasing scenarios analyzed. This compares to an increased probability of decline from $11 \%$ to $26 \%$ if the starting population was 100,000 , indicative of population estimates in the early 1970 s. Our approach accomplishes one of the main steps in a comprehensive cumulative effects assessment, namely the quantification of past, present, and foreseeable future projects on a valued ecosystem component, the Porcupine Caribou Herd. We suggest the testing of underlining assumptions and refinements of the model required to more fully estimate the impacts of development. The use of transparent, quantitative decision support tools in assessing industrial development impacts on Arctic wildlife becomes more critical as climatic changes to Arctic landscapes accelerate.
\end{abstract}

Key Words: Arctic National Wildlife Refuge; caribou; climate; cumulative effects; hydrocarbon; impact assessment; mitigation; modeling, Porcupine caribou

\section{INTRODUCTION}

In Canada and the U.S., proposals for resource development must provide not only a comprehensive assessment of potential impacts of new projects on wildlife resources, but also assess the new project's incremental impacts in relation to past, present, and foreseeable future projects. Termed a cumulative effects assessment (CEA), this requirement puts the focus on environmental sustainability and away from the assessment of individual project effects. Although simple in concept, researchers have found common failures in applying CEA (Duinker and Greig 2006, Gunn et al. 2011). Problems include a focus on project approval instead of environmental sustainability, poor understanding of ecological impact thresholds, inability to separate cumulative effects from project-specific impacts, and inappropriate handling of potential future developments. Further, Johnson and St.-Laurent (2011) commented on the lack of a methodological framework as a reason for slow progress on CEA. In addressing the methodological framework, Canter and Ross (2010) outlined steps that are generic to assessing cumulative effects. Among the steps is the need to quantitatively "connect" focal wildlife species to the project. Too often cumulative assessments are qualitative and, as a result, linkage of multiple stressors and natural variations is impossible. To make a quantitative connection, Johnston et al. (2019) argue for mechanistic models that can link individual-scale responses to population productivity. Mechanistic models can ask the "what if" questions required to assess existing and future stressors (Connolly et al. 2017).

Quantitatively linking key ecosystem components to proposed developments requires integrating knowledge and baseline data to assess potential project impacts. Although their use has been limited, simulation models are useful as a data integration tool to quantitatively address cumulative effects on wildlife (Wedeles et al. 2012). Studies designed to measure the influence of human activities on wildlife tend to deal with individual effects such as behavioral or physiological responses (Stankowich 2008, Fahrig and Rytwinski 2009) or less frequently, demographic responses such as changes in calf survival (Shively et al. 2005). Few authors have described responses to multiple disturbances or measures of population productivity (but see, Nellemann et al. 2000, 2003, Johnson et al. 2005). Behavioral, physiological, or distributional responses should be linked to population dynamics (Vistnes and Nellemann 2008), requiring projections such as energetic cost or change in reproduction and survival across a range of disturbance levels.

The abundance of migratory herds of caribou and wild reindeer (Rangifer tarandus) in circum-Arctic tundra regions has declined $56 \%$ over the last two decades (Russell et al. 2019). Herd size normally varies (Fauchald et al. 2017), but currently, some herds are at unprecedented low numbers. Five herds in Canada have declined more than $90 \%$ and show little sign of recovery, while four migratory tundra herds in northern Alaska have experienced significant, but less dramatic declines (Russell et al. 2019). There is growing concern regarding the ability of migratory tundra caribou to recover from herd lows, given the effects of changing climate and increased land-use activities across herds' ranges (Gunn et al. 2009). Thus, a more integrative approach is needed to address potential impacts of landscape and climate change on migratory caribou herds.

In this paper, we apply a cumulative effects modeling approach to quantitatively "connect" a caribou herd (Porcupine Caribou Herd, $\mathrm{PCH}$ ) to proposed hydrocarbon development in the Arctic National Wildlife Area Refuge (ANWR) of Alaska. The PCH

${ }^{1}$ Yukon University, Whitehorse, Yukon, ${ }^{2}$ CircumArctic Rangifer Monitoring and Assessment (CARMA) Network, ${ }^{3}$ Institute of Arctic Biology, University of Alaska Fairbanks, Fairbanks, Alaska, USA 
herd is critical to the sustainability of this Arctic landscape (Clough et al. 1987). It is also of vital importance to the cultural, spiritual, and subsistence lifeways of Inupiat, Inuvialuit, and Gwich'in communities of Canada and Alaska (Kofinas 1998, Bali and Kofinas 2008).

There has been pressure to open a portion of ANWR's coastal plain to oil development for over 50 years (Standlea 2006). To pass the 1980 Alaska National Interest Lands Conservation Act (U.S. Congress) establishing the Arctic National Wildlife Refuge, a compromise was agreed upon. Section 1002 of ANILCA set aside a portion of ANWR's coastal plain for the U.S. Congress to decide whether to allow oil and gas development on what was termed the "1002 lands." No Congress was able to pass legislation to open the area for development until lease sales were mandated in the 2017 U.S. Tax Cuts and Jobs Act. In fulfilling the requirements of the National Environmental Policy Act (NEPA), the U.S. Bureau of Land Management produced a draft environmental impact statement (BLM 2018) outlining a number of development options in preparation of lease sales.

Our objective was to provide a comparative quantitative assessment of six possible development options. We used a caribou cumulative effects (CCE) model that has evolved from a caribou energetics model (White et al.2014) to a cumulative effects model (Russell and Gunn 2019) through its application on project assessments across North America. Our focus was on the model structure, required data input and, relevant to our case example, the projected impacts of five hydrocarbon development scenarios proposed by the U.S. Bureau of Land Management (BLM 2018) to which we added a sixth, worst-case scenario.

\section{METHODS}

\section{The CCE Model}

A caribou energy-protein model has been developed and modified since the 1980s (see White et al. 2013, 2014). With each model application; data inputs have been refined, new research incorporated, and the model platform refined to reflect environmental sensitivity and stochasticity. With linkages to caribou movement and population demography, the model can now be used more easily to conduct a cumulative effects assessment. The current CCE model framework consists of three linked submodels (movement, energy-protein, and population; Fig. 1), which together allow scenario analyses of the cumulative effects of development and climate change.

The movement submodel is a GIS-based program that moves the caribou through the landscape based on historic collar data, and tracks daily vegetation type, climate, and location with respect to any development footprint. Individual path location data and attributes pass to the energy/protein submodel where natural environmental conditions dictate the proportion of the day that caribou will feed, rest, and move, thus impacting daily energy/ protein balance, milk production, calf growth, and cow and protein change. Climate indicators are required to set up any energy-protein submodel run and are obtained from a climate database developed within the CircumArctic Rangifer Monitoring and Assessment (CARMA) Network (Russell et al. 2013). Snow depth impacts energy expenditure during winter, both in travelling through the snow and in digging feeding craters to access forage (Russell et al. 1993). Energy balance is also impacted because of less time spent foraging and ingesting food, if snow is deep (Russell et al. 1993). Early spring snowmelt provides early green forage in late spring, coinciding with calving and postcalving (Finstad 2008). Warmer summers affect forage phenology leading to higher biomass but lower quality (digestibility and nitrogen; Finstad 2008). Warmer summers also mean higher insect harassment. Higher insect activity reduces foraging time, reduced feeding intensity, and increases standing, walking, and running (Russell et al. 1993). When, based on the movement submodel, a caribou is in the vicinity of human activity (called the zone of influence, ZOI), additional "costs" to the caribou are applied, resulting in an increase in walking and running and a decrease in feeding. Thus, the cost of being in a $\mathrm{ZOI}$ is increased energy expenditure and decreased food intake. The resultant lower energy/protein balance (intake minus expenditure) results in lower weight gain of the cow and, if lactating, lower milk production for her calf. From the energyprotein submodel, the fall body weight of the cow and her calf are used to determine the probability of the cow getting pregnant and the overwinter survival rate of the calf. This information, averaged across all movement paths, is passed on to the population submodel.

Fig. 1. Schematic of the caribou cumulative effects (CCE) model showing submodel components in red and various submodel inputs/outputs in blue.

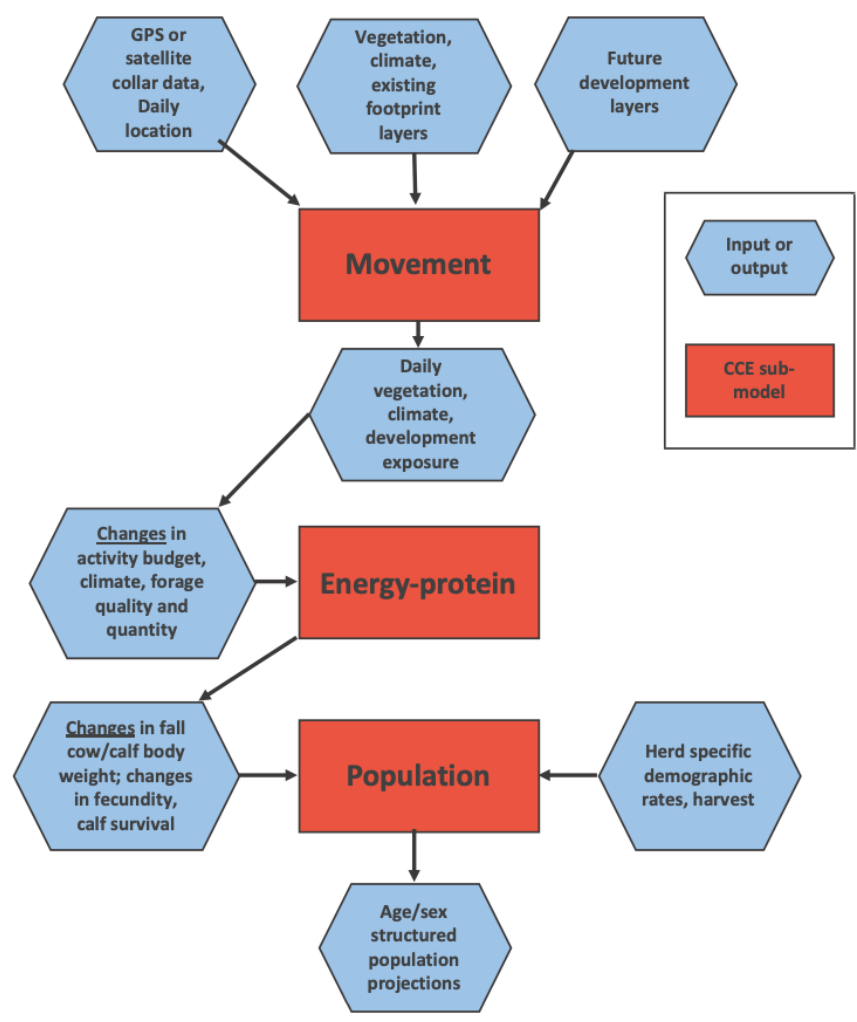

The population submodel simulates herd size, age structure, and sex ratios forward in time. Model inputs include initial herd size, age structure, sex ratio, pregnancy rates, mortality rates, harvest rates, and, for retrospective analyses, past herd size. 
The Porcupine Caribou Herd and the 1002 oil and gas development project

The Porcupine Caribou Herd $(\mathrm{PCH})$ migrates from taiga wintering ranges in Yukon, Northwest Territories, and Alaska to tundra calving and summer ranges adjacent the Beaufort Sea in Yukon and Alaska (Fig. 2). The herd peaked at 187,000 caribou in 1989 , declined to 123,000 by 2001 , then increased to 223,000 in 2017. In most years, use of 1002 lands by the PCH occurs from mid-May until mid-July, with the highest density during the postcalving and early summer period (Griffith et al. 2002). Calving, postcalving and early summer ranges were designated as the most sensitive habitats within the annual range of the herd by the International Porcupine Caribou Board (IPCB 1993). Radio-collars have been on the herd since the 1970s with satellite collars providing frequent location data since 1985. The collared caribou locations (totaling 414 caribou-years) were used in the movement submodel to analyze the current exposure of all 414 movement paths to existing and potential future human infrastructure.

Fig. 2. The range (red outline) of the Porcupine Caribou Herd in Alaska, Yukon, and Northwest Territories, showing the 1002 area (blue outline) of the National Arctic Wildlife Refuge.

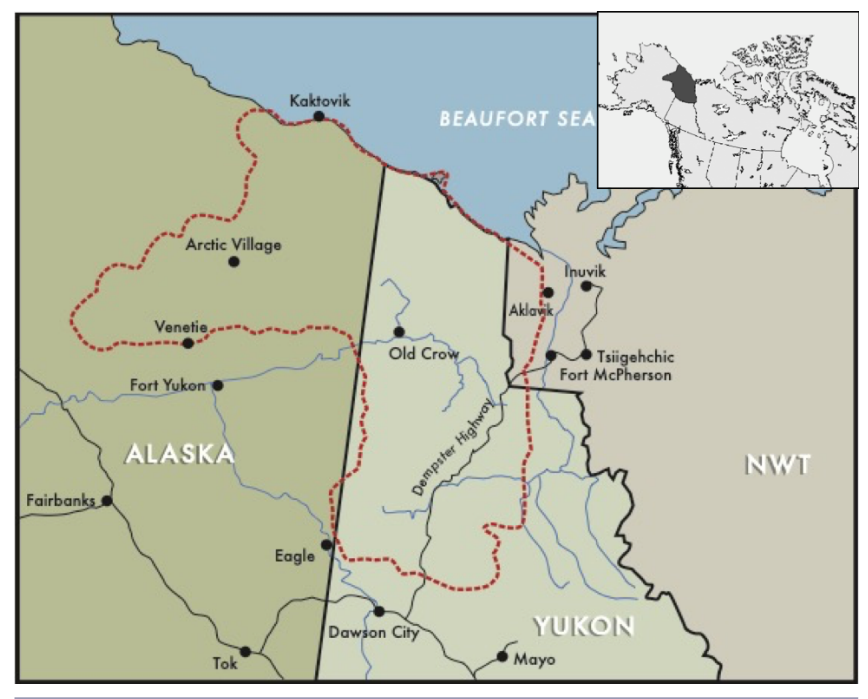

In December 2017, the U.S. Tax Act required the Bureau of Land Management (BLM) to implement an oil and gas leasing program in the Coastal Plain of the Arctic National Wildlife Refuge (ANWR) in Alaska (Comay et al. 2018; Fig. 2). Once issued a lease, companies are permitted to explore, drill, and produce oil or gas under specified environmental stipulations in exchange for royalty payments. BLM (2018) produced a Leasing Environmental Impact Assessment, which analyzes the environmental impact of five development scenarios. We evaluated six 1002 lands development scenarios (S1-S6) with S1S5 originating from the draft environmental impact statement (EIS; BLM 2018), while S6 is our worst-case future scenario (Fig. 3):

S1: Under S1, no land would be offered for lease in the 1002 lands. Although this option does not comply with the 2017 Tax Cuts and Jobs Act provisions, the scenario was modeled to represent current conditions, an absence of 1002 lands development.
S2 and S3: Under these two scenarios, portions of the 1002 lands would not be offered for lease to protect primarily calving and early postcalving distributions of the $\mathrm{PCH}$. As well, large portions of the rest of the area would be offered with "no surface occupancy," which would be open for mineral leasing but does not allow the construction of surface oil and gas facilities, other than road and pipeline access. A restriction termed "controlled use" also applies to about 15\% of the 1002 lands in S2 and S3. Controlled use allows some use and occupancy of public land, while protecting identified resources or values.

Fig. 3. The percent of days, while on 1002 area, collared caribou would spend in specific proposed lease stipulation areas for six development alternatives. "KIC" is Kaktovik Inupiat Land, native village corporation holdings within 1002 lands. Details of other stipulation areas explained in text.

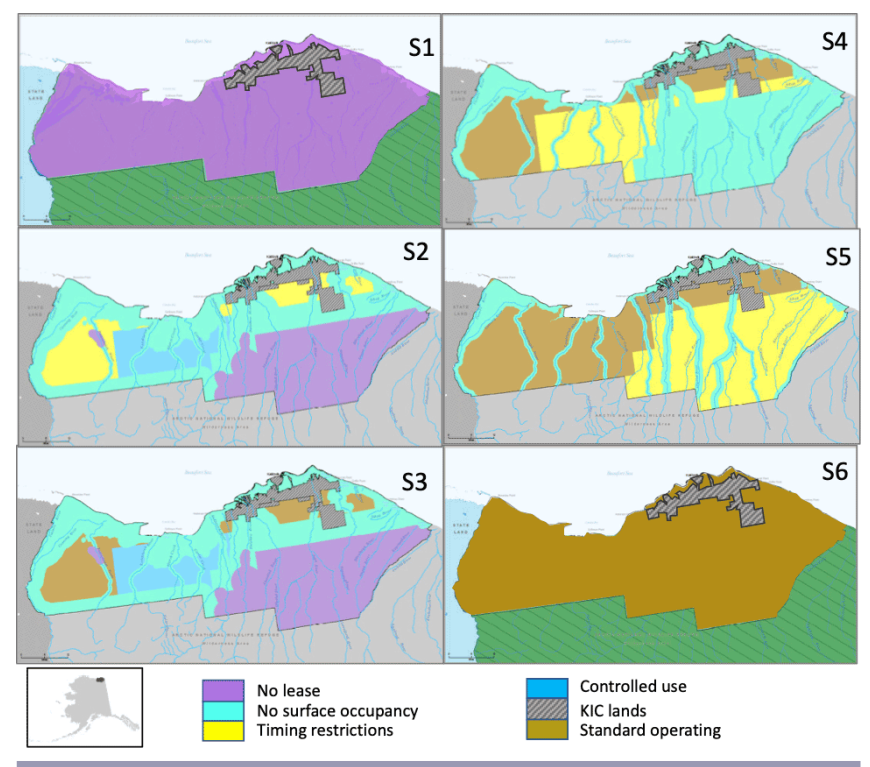

$\mathrm{S} 2$ and S3 are similar and have the same areas identified as no leasing. But where S2 has a timing restriction, S3 has standard operating procedures to mitigate impacts on caribou summer habitat. A timing restriction closes areas for specified seasonal time periods to construction, drilling, and other intensive operations but the stipulation does not close operation and basic maintenance, including associated vehicle travel, unless otherwise specified. Under the standard operating stipulation, development must meet basic operating mitigations with no additional special restrictions.

S4: The entire program area could be offered for lease sale under S4; however, a large area (primarily calving and postcalving areas) would be subject to no surface occupancy (described above).

S5: The entire program area could be offered for lease sale: calving and postcalving areas would be subject to a timing restriction, while most of the remaining area would be under standard operating restrictions.

S6: Scenario 6 was not an option in the Draft EIS, but we included it as a worst-case future scenario. It assumes economically recoverable oil and gas throughout the 1002 lands is developed with no mitigation beyond the standard operating restrictions. 
Table 1. Penalties (percent changes) in baseline activity budgets used in the caribou cumulative effects (CCE) model based on mitigations outlined under different lease stipulations. "KIC" is Kaktovik Inupiat Land, native village corporation holdings within 1002 lands.

\begin{tabular}{|c|c|c|c|c|c|c|}
\hline Lease stipulation & Season & Foraging & Walk & Run & $\begin{array}{l}\text { Eating } \\
\text { Intensity }\end{array}$ & Rationale \\
\hline \multirow[t]{3}{*}{ Timing } & Precalving & -4 & 2 & 2 & -2 & \multirow{3}{*}{$\begin{array}{l}\text { Assumes } 20 \text { May to } 16 \text { July; what activity allowed } \\
\text { undefined }\end{array}$} \\
\hline & Calving - postcalving & -8 & 4 & 4 & -4 & \\
\hline & Early - midsummer & -12 & 6 & 6 & -6 & \\
\hline \multirow[t]{3}{*}{ No surface occupancy } & Precalving & -3 & 1.5 & 1.5 & -1.5 & \multirow{3}{*}{$\begin{array}{l}\text { Adjacent activity zones; pipelines, roads, and gravel pits } \\
\text { are allowed (No oil and gas facilities); designation can } \\
\text { be changed in field; less strong protection than no lease }\end{array}$} \\
\hline & Calving - postcalving & -6 & 3 & 3 & -3 & \\
\hline & Early - midsummer & -6 & 3 & 3 & -3 & \\
\hline \multirow[t]{3}{*}{ Standard operating } & Precalving & -6 & 3 & 3 & -3 & \multirow[t]{3}{*}{ Assumes standard zone of influence (ZOI) penalties } \\
\hline & Calving - postcalving & -12 & 6 & 6 & -6 & \\
\hline & Early - midsummer & -12 & 6 & 6 & -6 & \\
\hline \multirow[t]{3}{*}{ KIC lands } & Precalving & -6 & 3 & 3 & -3 & \multirow[t]{3}{*}{ Development and lease conditions undefined } \\
\hline & Calving - postcalving & -12 & 6 & 6 & -6 & \\
\hline & Early - midsummer & -12 & 6 & 6 & -6 & \\
\hline \multirow[t]{3}{*}{ No lease } & Precalving & 0 & 0 & 0 & 0 & \multirow{3}{*}{$\begin{array}{l}\text { Not in a ZOI although if development is directly } \\
\text { adjacent to the no lease zone, displacement and } \\
\text { disturbance will occur near the boundary zone }\end{array}$} \\
\hline & Calving - postcalving & 0 & 0 & 0 & 0 & \\
\hline & Early - midsummer & 0 & 0 & 0 & 0 & \\
\hline \multirow[t]{3}{*}{ Controlled use } & Precalving & -4 & 2 & 2 & -2 & \multirow[t]{3}{*}{ Unclear how controlled use will mitigate } \\
\hline & Calving - postcalving & -12 & 6 & 6 & -6 & \\
\hline & Early - midsummer & -12 & 6 & 6 & -6 & \\
\hline
\end{tabular}

\section{Populating the model}

In S1 (no lease sales), if a collared caribou entered the ZOI of any development, we assigned a "penalty." The penalty amounts to change in daily activity budget by spending less time foraging and more time walking and running. As well the proportion of time that a caribou spent ingesting food (eating intensity) rather than searching while in the foraging period was also reduced. If under S1 the caribou was in the 1002 lands, no penalty was assigned because S1 assumes no leases would be offered. In contrast under S6, when a caribou enters the 1002 lands, the full development with standard mitigation, the activity penalty was assigned to a caribou while anywhere in 1002 lands. Thus, comparing the results of $\mathrm{S} 1$ to $\mathrm{S} 6$ represents the cost to the $\mathrm{PCH}$ under a worst-case scenario.

In our modeling, during most of the year (1 September-31 May), we have assumed a penalty for being in the $\mathrm{ZOI}$ is $6 \%$ decrease in foraging, $3 \%$ increase in walking, $3 \%$ increase in running, and $3 \%$ decline in feeding intensity (the $\%$ of the foraging time actually spent ingesting food). However, we doubled these "base" penalties for the calving, postcalving, and summer period (1 June-31 August). The doubling was based on the common thread through the literature to suggest that cows and newborn calves are most sensitive to human disturbance during the calving (Cameron et al. 1992, Wolfe et al. 2000, Vistnes and Nellemann 2001, Reimers and Coleman 2006) and postcalving when lactating cows' daily requirement for energy and protein doubles (Russell et al. 1993). During the postcalving and summer period larger and larger aggregations begin to form, partially or wholly in response to insect harassment. The larger the group, the less likely they will be able to successfully cross through development zones (Smith and Cameron 1985). Thus, during calving, postcalving, and summer, the doubled penalties in the ZOI of development were a decrease of $12 \%$ feeding, $6 \%$ increase in walking, a $6 \%$ increase in running, and a $6 \%$ decline in feeding intensity. These values apply when caribou were in areas where standard operating mitigation was in effect.
To differentiate impacts when caribou were in the lease stipulation areas other than standard operating procedures, we reduced the activity penalties to the degree we were certain from the EIS (BLM 2018) that disturbance would be mitigated and whether the mitigation would be effective. We used our experience of caribou behavior and disturbance to scale the costs relative to each other because there is a lack of specific knowledge about how caribou will respond to the activities permitted under the different stipulations (Table 1). On the one hand, the model may underestimate disturbance costs because the penalties are based on changes in feeding, resting, and moving, and do not include any other costs such as costs of displacement, stress, or increased responsiveness when hunting is associated with infrastructure (Plante et al. 2018). On the other hand, the model assumes that caribou are exposed to disturbance anywhere in the lease stipulation area as the pattern of development (spatial footprint) is not specified at this stage.

\section{Movement submodel runs}

The Porcupine Caribou Management Board provided a vegetation map layer and an existing development footprint layer. In the model, all scenarios incorporate these layers and thus, the baseline scenario (S1) represents the current development landscape for the $\mathrm{PCH}$. The lease stipulation zonal maps from Figure 3 were digitized to represent scenarios S2--S6.

Daily location of 414 annual caribou pathway, between 1985 and 2017, were available from satellite collars and run through the movement submodel. Thus, output from the movement submodel was daily location of each caribou, daily vegetation type, climate zone, and whether the caribou was either in a ZOI of existing development footprint or in any of the 1002 lands lease stipulation zones. Output was then passed on to the energy-protein submodel.

\section{Energy/Protein submodel runs}

The energy-protein model output for each development scenario was fall cow and calf weight for the 414 movement paths. We used, as the baseline value, the average fall cow weight determined from 
our results of current development (S1). For the other five alternatives (S2-S6), departures from this baseline weight were calculated. Fall weight of the cow is correlated to the probability that the cow will become pregnant, first published for the Central Arctic Herd (Cameron and ver Hoef 1994) and applied to the PCH (Russell et al. 1996). Using these relationships, assuming an average body weight of $81 \mathrm{~kg}$, a body weight drop of $0.6 \mathrm{~kg}$ equates to a decline in the probability of pregnancy of $1.15 \%$.

Fall calf body weight is related to overwinter calf survival. For example, in the Central Arctic Herd, calves that were heavier in September were more likely to survive the following winter (Arthur and Del Vecchio 2009). From their data, a $1 \mathrm{~kg}$ decline from baseline calf body weight equated with a $5 \%$ decrease in overwinter survival. Using the fall body weight modeled for the current development option (S1) as the base weight, departures from calf body weight were converted to departures from base overwinter survival.

\section{Population submodel runs}

We explored overwinter calf survival and cow probability of pregnancy for the six development scenarios in the population submodel. To determine the potential impact of oil and gas development in the 1002 lands on the PCH throughout the herd's cycle of abundance, we ran two scenarios: (1) starting at the current herd size of the PCH $(218,000)$ and (2) starting at the historic herd low $(100,000)$. To encompass all possible future outcomes, we ran the population model 1000 times (iterations) for each development option randomly assigning a base pregnancy rate and adult cow mortality for each run. These random values were based on historic mean and standard deviation for pregnancy rates and adult cow mortality. Annual mortality rates did not include harvest. We ran the population submodel over 10 years and calculated the exponential rate of change and classified each iteration into declining ( $<-4 \%$ change), stable ( $\geq 4 \%$ and $\leq 4 \%$ change) and increasing ( $>4 \%$ change). The $4 \%$ value is based on the relative precision of population estimates for migratory tundra herds.

\section{RESULTS}

\section{Movement submodel}

Movement paths in the 1002 lands based on the 414 caribou-years (Fig. 4) showed that $67 \%$ of the collared cows entered 1002, although the annual variability was high. Annually, collared cows spent on average $9.8( \pm 10.42)$ days on the 1002 lands, ranging from 0 to 43 days. Cows that occupied the 1002 lands primarily spent $53 \%$ of total encounter days ( 2346 of 4416 collar-days) in the postcalving period (11-30 June). For our assessment of potential impacts, we determined in what lease stipulation areas these encounters occurred. Figure 5 summarizes the percent of encounter days spent in lease stipulation areas for each scenario.

\section{Energy-protein submodel}

Using the modeled output body weights from the current development scenario (S1) as the base, we determined the incremental cost of 1002 lands development for the remaining five development alternatives (Fig. 6). The added development cost to fall body weight was a decrease in fall body weight of the cows from $0.24 \mathrm{~kg}$ (S2) to $0.44 \mathrm{~kg}$ (S6) and $0.69-1.7 \mathrm{~kg}$ for the calves. Based on our relationships between body weight and vital rates, this translates into a drop of $0.5 \%$ to $1 \%$ in probability of pregnancy and $1 \%$ to $8.5 \%$ increase in overwinter calf mortality.
Fig. 4. Seasonal movement paths of radio-collared Porcupine Caribou cows from 1986 to 2018 in relation to the 1002 area in Alaska.

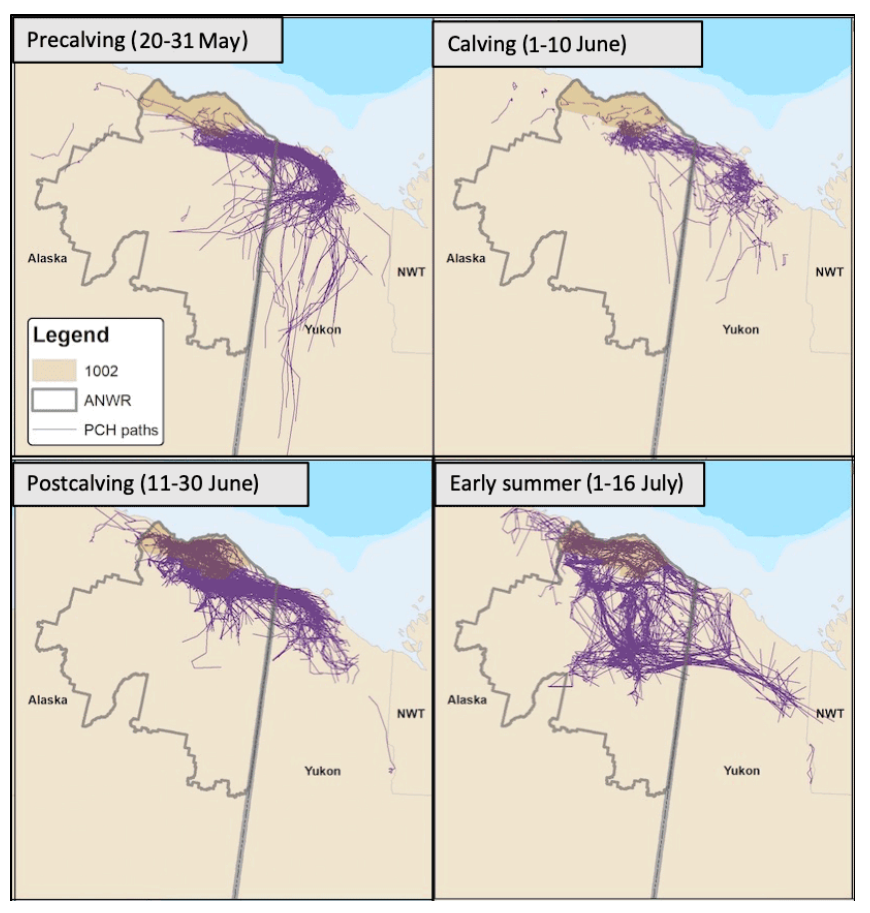

Fig. 5. The percent of days, while on 1002 lands, collared caribou would spend in specific proposed lease stipulation areas for six development alternatives. "KIC" is Kaktovik Inupiat Land, native village corporation holdings within 1002 lands. Details of other stipulation areas explained in text.

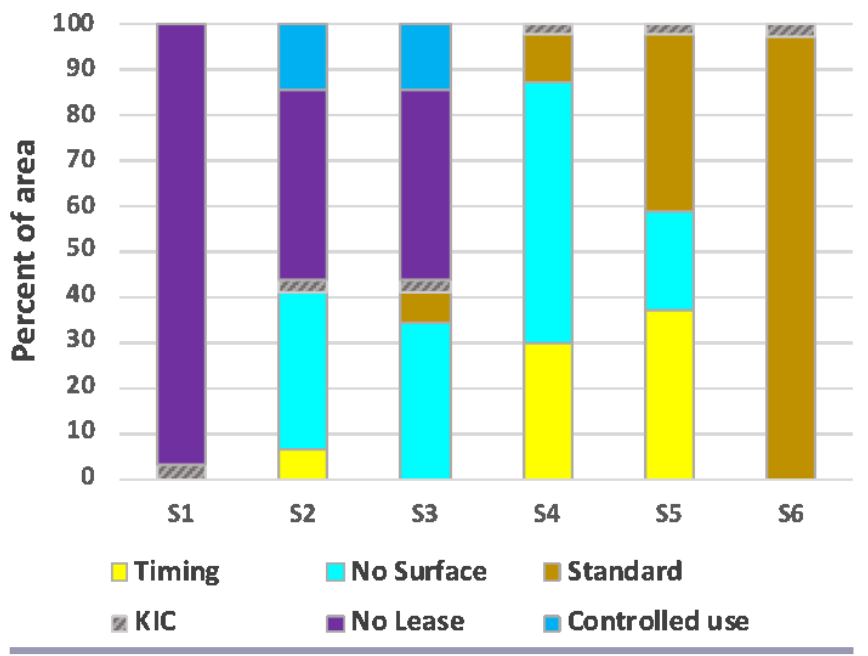

\section{Population submodel}

When we ran these scenario results through the population submodel, we found a higher probability of a decline in the $\mathrm{PCH}$ after 10 years from the lower starting herd size (100,000; Fig. 7). At the extremes (S1 versus S6) we found from $29 \%$ (S1) to $55 \%$ 
(S6) probability of a decline with a starting herd size of 100,000 compared to from $13 \%(\mathrm{~S} 1)$ to $32 \%$ (S6) probability of a decline starting at 218,000 caribou. The worst-case scenario (S6) was an increased probability of a decline of $26 \%(29 \%-55 \%)$ with a starting herd of 100,000 caribou, compared to a $19 \%(32 \%-13 \%)$ increased probability of a decline with a starting herd size of 218,000 caribou.

Fig. 6. The cost to fall cow and calf weights associated with each of the six development scenarios $(+95 \mathrm{CI})$.

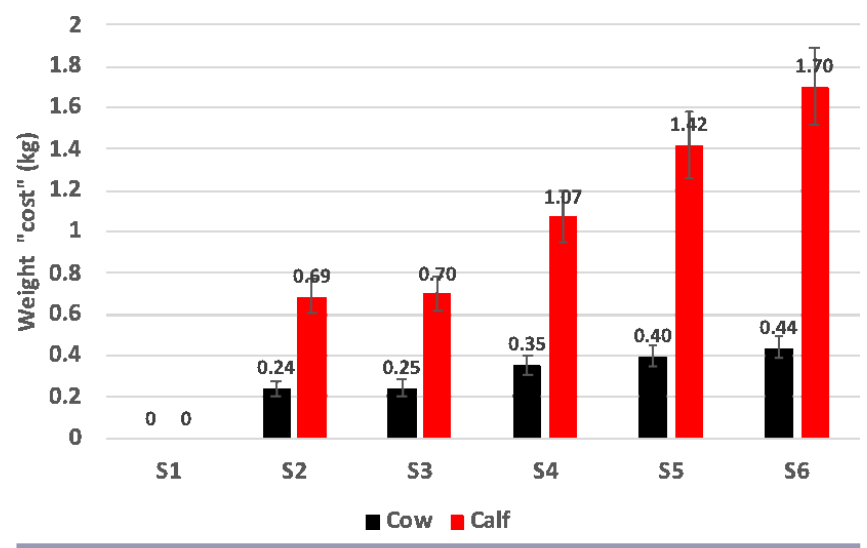

Fig. 7. Percent probability of a decline in the Porcupine Caribou Herd under six development scenarios for a starting population size and 100,000 and 218,000.

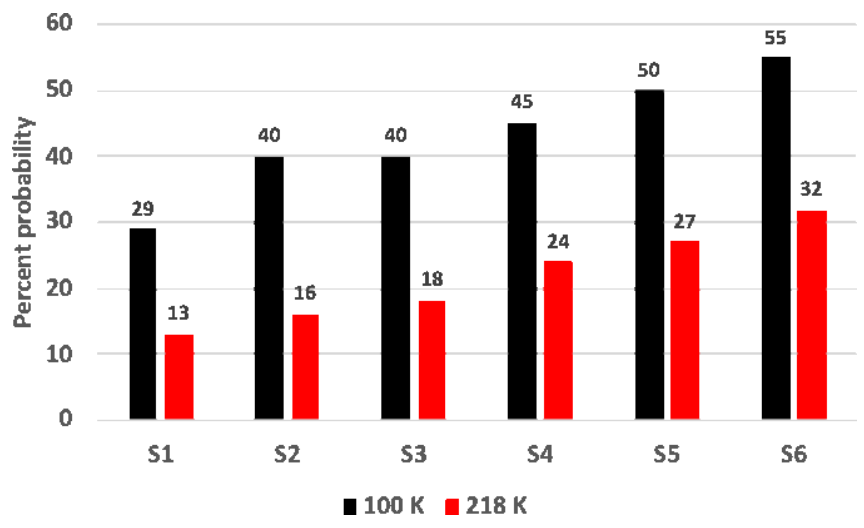

\section{DISCUSSION}

We quantified potential cumulative effects of existing and potential development on the Porcupine Caribou Herd in the 1002 lands of the Coastal Plains. Our quantitative analysis compares scenarios ranging from current development to a theoretical worst case of extensive development. We projected an $11 \%$ to $21 \%$ increased probability of a decline if the $\mathrm{PCH}$ was at 100,000 caribou when development started (S2 versus S5; Fig. 7). These equivalent values for the current herd size (218,000 caribou) are a $3 \%$ to $14 \%$ increase in the probability of a decline (Fig. 7).

A key assumption in our analyses of the different scenarios was the behavioral costs that we used to penalize caribou being within the ZOI (Table 1). We based our assumption on reviews of undisturbed activity patterns compared to altered activity patterns when caribou are close to human activity or infrastructure (Wolfe et al. 2000, Vistnes and Nellemann 2008). Although most studies document a reduction in feeding and increase in walking and running, the data are equivocal, because many factors impact caribou activity (time of day, season, forage quality and quantity, snow depths, insect harassment).

We also recognize that modeling caribou movement through the landscape is based on historical movements as reflected in satellite collar locations. Thus, the question we are answering is, "what are the potential impacts of new infrastructure if historic caribou movement patterns continued?" To explore consequences if movement patterns changed, we would need a movement model that can dynamically move animals through a developed landscape (see Panzacchi et al. 2016). To construct such a model, we need to understand the choices caribou make when they encounter development. We also need a finer scale understanding of the energy and protein balance from selecting different habitats especially under a warmer climate.

Our modeling has been fine-tuned through case histories over 20 years, and we have applied the model to nine migratory tundra herds as a means of integrating field data to assess cumulative effects. Applications include energy consequences of low flying fighter jet aircraft (Delta caribou herd: Luick et al. 1996), road and pipeline effects at Prudhoe Bay (Central Arctic herd: Murphy et al. 2000), effects of climate change (PCH: Russell et al. 1996), summer range assessment (George River Herd: Manseau 1996), and proposed developments (e.g., North Baffin Herd: Russell 2012, 2014a; Qamanirjuaq Herd: Russell 2014b; Bathurst Herd: Gunn et al. 2011, BCRP 2018; Dolphin and Union Herd and Ahiak herds: Russell 2018, unpublished report submitted to Environmental Resources Management). With each model application, data inputs have been refined, new research incorporated, and model platform refined to better reflect environmental sensitivity and stochasticity.

In assessing impacts from development, we considered long-term implications. The PCH is currently at an historic high, while many other herds across the North are close to historic lows. Thus, in modeling potential impacts at the population level, we considered current population status (218,000 caribou), and, as well, assumed that the herd could in the next decade or so drop to historic lows $(100,000$ in the early 1970 s). We determined that the impacts of hydrocarbon activity within 1002 lands would be more pronounced if the $\mathrm{PCH}$ was at a lower population size when development began.

Our modeling is a response to the compelling reasons for a comprehensive and quantitative CEA of the potential leasing program in the 1002 Lands for the PCH. The potential leasing program is within the U.S. National Wildlife Refuge system. The 1997 National Wildlife Refuge System Improvement Act listed three priority levels of use of Wildlife Refuges from highest to lowest priority: (1) conservation; (2) wildlife-dependent recreation; and (3) other uses. Oil development falls in the lowest position in this hierarchy and faces additional tests of compatibility (Tanus 2012). Second, in 1987 the Government of Canada and the Government of the United States of America signed an international agreement on the conservation of the PCH (Canada and United States 1987). The agreement makes 
specific reference to the country-to-country consultation that is required prior to the final decision if the activity is likely to cause significant, long-term, adverse impacts, including cumulative impacts, to the herd or its habitat. Moreover, the agreement states that countries should avoid activities that lessen the ability of users of Porcupine Caribou to use the herd.

Declines in herd size relative to the sustainability of subsistence harvest (about $90 \%$ of the current harvest) is of long-standing concern. In anticipation of a possible future decline in $\mathrm{PCH}$ population, the Canadian Porcupine Caribou Management Board, a comanagement body of users and managers, established a harvest management plan identifying four zones of risk related to population size, and for each zone, an agreed upon appropriate harvest restriction (PCMB 2010). Russell and Gunn (2019), interpreted the model results summarized in this paper to the probability that future population size would fall into one of the four harvest risk zones. Depending on the development scenario, they found a $9 \%-23 \%$ higher probability that managers would have to impose more restrictive harvest regimes to trade off the costs of 1002 lands development, assuming low starting population size and average climate. Thus from our analysis there is potential for 1002 development to lessen the ability of users of Porcupine Caribou to harvest the herd.

\section{CONCLUSIONS}

Responsible hydrocarbon development in Arctic Alaska requires the capability to integrate environmental data across multiple scales. With respect to impacts on a migratory caribou herd that scale ranges well beyond the boundaries of the proposed development area. We argue that integrating data for such a complex environment requires a decision support tool that clearly states the assumptions, data requirements, and provides output based on risk. A successful decision support tool is best measured by the extent to which the tool gives insight, stimulates discussion, inspires innovation, and/or helps to resolve societal problems (Kofinas et al. 2016).

We employed a CCE model that acknowledges the complexity of the caribou eco-socio-system, admits when data are equivocal, is explicit in what assumptions go into the model, and provides projections on the basis of risk, e.g., chance of herd declining. Doing so enables "caribou people," wildlife, and land managers to evaluate risks and trade-offs inherent in development. In the context of resolving or reducing the development costs for the $\mathrm{PCH}$ we have proposed a response framework to apply monitoring and mitigation within an adaptive comanagement system to support the "caribou people" as they face decisions cascading from a warmer climate and developments (Gunn et al. 2014). We would argue that the use of transparent, quantitative decision-support tools in assessing industrial development impacts on Arctic wildlife becomes more critical as climatic changes to Arctic landscapes accelerate.

Responses to this article can be read online at: https://www.ecologyandsociety.org/issues/responses. php/12105

\section{Acknowledgments:}

We thank Craig Machtans, Shannon Stotyn, Mike Suitor, Marsha Brannigan, and Gary Kofinas for helpful suggestions throughout the writing of this manuscript. We also thank the two anonymous reviewers for helpful comments. Funding for the cumulative effects assessment was provided by Governments of Canada, Yukon, and Northwest Territories.

\section{Data Availability:}

The data that support the findings of this study are available on request from the corresponding author, [DR]. Much of the datal code are not publicly available because of limited availability from Management Agencies (for example radio-collar locations require special permission for one time use). Demographic data for the $P C H$ was obtained from Alaska Department Fish and Game reports, see: http://www.adfg.alaska.gov/static/research/wildlifel

speciesmanagementreports/pdfs/caribou 2015 chapter 15 porcupine. pdf. Complete list of Equations incorporated in to the EnergyProtein model are found in White et al 2014.

\section{LITERATURE CITED}

Arthur, S. M., and P. A. Del Vecchio. 2009. Effects of oil field development on calf production and survival in the Central Arctic herd. Alaska Department of Fish and Game. Federal Aid in Wildlife Restoration. Final Research Technical Report. Grants W-27-5 and W-33- 1 through W-33-4. Project 3.46. Juneau, Alaska, USA.

Bali, A., and G. Kofinas. 2008. Voices of Caribou People. Conservation of Arctic Flora and Fauna, Akureyri, Iceland. [online] URL: https://carma.caff.is/index.php/caribou-people/540carma/projects/563-voices-of-the-caribou-people

Bathurst Caribou Range Plan (BCRP). 2018. Methods and summary of key results for Bathurst Caribou Range Plan using the CircumArctic Rangifer Monitoring and Assessment (CARMA) Integrated Caribou Model. Appendix D in Bathurst Caribou Range Plan, Supporting Report: Caribou Technical Information and Range Assessment. Environment and Natural Resources, Yellowknife, Northwest Territories, Canada. [online] URL: https://www.enr.gov.nt.ca/sites/enr/files/resources/draft_caribou range assessment and technical information.pdf

Bureau of Land Management (BLM). 2018. Coastal plain oil and gas leasing program draft environmental impact statement. Bureau of Land Management, Washington, D.C., USA. [online] URL: https://eplanning.blm.gov/public_projects/nepa/102555/164448/200585/ Coastal Plain Draft EIS Volume 1.pdf

Cameron, R. D., D. J. Reed, J. R. Dau, and W. T. Smith. 1992. Redistribution of calving caribou in response to oil field development on the Arctic slope of Alaska. Arctic 45:327-413. https://doi.org/10.14430/arctic1412

Cameron, R. D., and J. M. Ver Hoef. 1994. Predicting parturition rate of caribou from autumn body mass. Journal of Wildlife Management 58(4):674-679. https://doi.org/10.2307/3809681

Canada and United States. 1987. Agreement between the Government of Canada and the Government of the United States 
of America on the Conservation of The Porcupine Caribou. Government of Canada, Ottawa, Ontario, Canada and the Government of the USA, Washington, D.C., USA. [online] URL: https://www.treaty-accord.gc.ca/text-texte.aspx?id=100687

Canter, L., and B. Ross. 2010. State of practice of cumulative effects assessment and management: the good, the bad and the ugly. Impact Assessment and Project Appraisal 28:261-268. https:// doi.org/10.3152/146155110X12838715793200

Clough, N. K., P. C. Patton, and A. C. Christiansen, editors. 1987. Arctic National Wildlife Refuge, Alaska, Coastal Plain Resource Assessment: report and recommendation to the Congress of the United States and Final Legislative Environmental Impact Statement. Vol. 1. U.S. Fish and Wildlife Service, U.S. Geological Survey, and Bureau of Land Management, Washington, D.C., USA. [online] URL: https://pubs.usgs.gov/fedgov/70039559/ report.pdf

Comay, L. B., M. Ratner, and R. E. Crafton. 2018. Arctic National Wildlife Refuge (ANWR): an overview. U.S. Congressional Research Service, RL33872, Washington, D.C., USA. [online] URL: https://fas.org/sgp/crs/misc/RL33872.pdf

Connolly, S. R., S. A. Keith, R. K. Colwell, and C. Rahbek. 2017. Process, mechanism, and modeling in macroecology. Trends in Ecology \& Evolution 32(11):835-844. https://doi.org/10.1016/j. tree.2017.08.011

Duinker, P. N., and L. A. Greig. 2006. The importance of cumulative effects assessment in Canada: ailments and ideas for redeployment. Environmental Management 37:153-161. https:// doi.org/10.1007/s00267-004-0240-5

Fahrig, L., and T. Rytwinski. 2009. Effects of roads on animal abundance: an empirical review and synthesis. Ecology and Society 14(1):21. https://doi.org/10.5751/ES-02815-140121

Fauchald, P., T. Park, H. Tømmervik, R. Myneni, and V. H. Hausner. 2017. Arctic greening from warming promotes declines in caribou populations. Science Advances 3:e1601365. https://doi. org/10.1126/sciadv.1601365

Finstad, G. L. 2008. Applied range ecology of reindeer (Rangifer tarandus tarandus) on the Seward Peninsula, Alaska. Dissertation. University of Alaska, Fairbanks, Alaska, USA. https://doi.org/10.7557/2.28.1.154

Griffith, D. B., D. C. Douglas, N. E. Walsh, D. D. Young, T. R. McCabe, D. E. Russell, R. G. White, R. D. Cameron, and K. R. Whitten. 2002. The Porcupine Caribou Herd. Pages 8-37 in D. C. Douglas, P. E. Reynolds, and E. B. Rhode, editors. Arctic Refuge coastal plain terrestrial wildlife research summaries. USGS/BRD/ BSR-2002-0001. U.S. Geological Survey, Biological Resources Division, Biological Science Report, Washington, D.C., USA.

Gunn, A., C. J. Johnson, J. S. Nishi, C. J. Daniel, M. Carlson, D. E. Russell, and J. Z. Adamczewski. 2011. Addressing cumulative effects in the Canadian central Arctic: understanding the impacts of human activities on barren-ground caribou. Chapter 8 in P. R. Krausman and L. K. Harris, editors. Cumulative effects in wildlife management: a critical aspect of impact mitigation. Taylor and Francis, Boca Raton, Florida, USA.

Gunn, A., D. Russell, and L. Greig. 2014. Insights into integrating cumulative effects and collaborative co-management for migratory tundra caribou herds in the Northwest Territories, Canada. Ecology and Society 19(4):4. https://doi.org/10.5751/ ES-06856-190404

Gunn, A., D. E. Russell, R. G. White, and G. Kofinas. 2009. Facing a future of change: wild migratory caribou and reindeer. Arctic 62(3):257-369. http://dx.doi.org/10.14430/arctic145

International Porcupine Caribou Board (IPCB). 1993. Sensitive habitats of the Porcupine Caribou Herd. Report of the International Porcupine Caribou Board by the Porcupine Technical Committee, United States and Canada. [online] URL: https://www.pcmb.ca/documents/Sensitive $\% 20$ Habitats $\% 20$ of $\% 20$ the $\%$

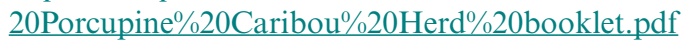

Johnson, C. J., M. S. Boyce, R. L. Case, H. D. Cluff, R. J. Gau, A. Gunn, and R. Mulders. 2005. Cumulative effects of human developments on Arctic wildlife. Wildlife Monographs 160:1-36.

Johnson, C. J., and M. H. St.-Laurent. 2011. Unifying framework for understanding impacts of human developments on wildlife. Pages 27-54 in D. E. Naugle, editor. Energy development and wildlife conservation in western North America. Island, Washington, D.C., USA. https://doi.org/10.5822/978-1-61091-022-4_3

Johnston, A. S. A., R. J. Boyd, J. W. Watson, A. Paul, L. C. Evans, E. L. Gardner, and V. L. Boult. 2019. Predicting population responses to environmental change from individual-level mechanisms: towards a standardized mechanistic approach. Proceedings of the Royal Society B: Biological Sciences 286(1913). https://doi.org/10.1098/rspb.2019.1916

Kofinas, G. P. 1998. The costs of power sharing: community involvement in Canadian Porcupine Caribou co-management. Dissertation. The University of British Columbia, Vancouver, British Columbia, Canada. [online] URL: https://open.library. ubc.ca/collections/831/items/1.0088701

Kofinas, G., S. Abdelrahim, M. Carson, F. S. Chapin III, J. Clement, N. Fresco, A. Gunn, G. Peterson, A. N. Petrov, A. Quinlan, M. Sommerkorn, and A. Veazey. 2016. Building resilience in the Arctic: from theory to practice. Pages 180-208 in M. Carson and G. Peterson, editors. Arctic Resilience Report. Arctic Council, Stockholm Environment Institute and Stockholm Resilience Centre, Stockholm, Sweden. [online] URL: https:// www.researchgate.net/publication/311571985 Building resilience in the Arctic_From theory to practice

Luick, B. R., J. A. Kitchens, R. G. White, and S. M. Murphy. 1996. Modeling energy and reproductive costs in caribou exposed to low flying military jet aircraft. Rangifer 16(4):209-121. https://doi. org/10.7557/2.16.4.1244

Manseau, M. 1996. Relation Réciproque Entre les Caribous et la Végétation des Aires d'Estivage: Le Cas du Troupeau de Caribous de la Rivière George. Dissertation. Université Laval, Ste-Foy, Québec, Canada.

Murphy, S. M., D. E. Russell, and R. G. White. 2000. Modeling energetic and demographic consequences of caribou interactions with oil development in the Arctic. Rangifer Special Issue 12:107-109.

Nellemann, C., P. Jordhøy, O.-G. Støen, and O. Strand. 2000. Cumulative impacts of tourist resorts on wild reindeer (Rangifer 
tarandus tarandus) during winter. Arctic 53:9-17. https://doi. org/10.14430/arctic829

Nellemann, C., I. Vistnes, P. Jordhøy, O. Strand, and A. Newton. 2003. Progressive impact of piecemeal infrastructure development on wild reindeer. Biological Conservation 113:307-317. https://doi.org/10.1016/S0006-3207(03)00048-X

Panzacchi, M., B. Van Moorter, O. Strand, M. Saerens, I. Kivimäki, C. C. St. Clair, I. Herfindal, and L. Boitani. 2016. Predicting the continuum between corridors and barriers to animal movements using Step Selection Functions and Randomized Shortest Paths. Journal of Animal Ecology 85:32-42. https://doi.org/10.1111/1365-2656.12386

Plante, S., C. Dussault, J. H. Richard, and S. Côté. 2018. Human disturbance effects and cumulative habitat loss in endangered migratory caribou. Biological Conservation 224:129-143. https:// doi.org/10.1016/j.biocon.2018.05.022

Porcupine Caribou Management Board (PCMB). 2010. Harvest management plan for the Porcupine Caribou Herd in Canada. PCMB, Whitehorse, Yukon, Canada. [online] URL: http://www. pcmb.ca/documents/Harvest $\%$ 20Management $\% 20$ Plan $\% 202010$. pdf

Reimers, E., and J. E. Colman. 2006. Reindeer and caribou (Rangifer tarandus) response towards human activities. Rangifer 26:55-71. https://doi.org/10.7557/2.26.2.188

Russell, D. 2012. Energy-protein modeling of North Baffin caribou in relation to the Mary River mine project. Appendix $6 \mathrm{H}$ in Mary River Project Final Environmental Effect Statement. Volume 6 - Terrestrial Environment. Baffinland Iron Mines Corporation, Oakville, Ontario, Canada. [online] URL: ftp://ftp. nwb-oen.ca/registry $/ 2 \% 20$ MINING $\% 20$ MILLING/2A/2AM $\% 20$ \%20Mining/2AM-MRY1325\%20BIMC/1\%20APPLICATION/Final $\%$ 20Environmental $\% 20$ Impact $\% 20$ Statement/Volume $\% 2006 /$ Appendix $\%$ $206 \mathrm{H} \% 20$ Energetics $\% 20$ of $\% 20$ Caribou/ $/ 212 \% 20$ Appendix $\% 206 \mathrm{H}^{\circ} \%$ 20Energetics $\% 20$ of $\% 20$ Caribou.pdf

Russell, D. 2014a. Energy-protein modeling of North Baffin Island caribou in relation to the Mary River Project: a reassessment from Russell (2012). Prepared for EDI Environmental Dynamics Inc., Whitehorse, Yukon and Baffinland Iron Mines Corporation, Oakville, Ontario, Canada.

Russell, D. E. 2014b. Kiggavik Project effects: energy-protein and population modeling of the Qamanirjuaq caribou herd. Prepared for EDI Environmental Dynamics Inc., Whitehorse, Yukon and AREVA Resources Canada, Saskatoon, Saskatchewan, Canada. [online] URL: http://reviewboard.ca/upload/project_document/ EA1314-01 Energy Protein model for caribou -

Kiggavik_Project_Effects.PDF

Russell, D., and A. Gunn. 2019. Vulnerability analysis of the Porcupine Caribou Herd to potential development of the 1002 lands in the Arctic National Wildlife Refuge, Alaska. Report prepared for: Environment Yukon, Canadian Wildlife Service, and GNWT Department of Environment and Natural Resources, Yellowknife, Northwest Territories, Canada. [online] URL: https://www.pcmb.ca/PDF/1002/Russell\%20and $\% 20$ Gunn $\% 202019 \%$ 20PCH $\% 20$ vulnerability $\% 201002 \% 20$ Final.pdf
Russell, D. E., A. Gunn, and S. Kutz. 2019. Migratory tundra caribou and wild reindeer. Pages 67-73 in E. Osborne, J. RichterMenge, and M. Jeffries, editors. Arctic Report Card: Update for 2018. National Oceanic and Atmospheric Administration, Washington, D.C., USA. [online] URL: https://www.arctic.noaa. gov/Report-Card/Report-Card-2018/ArtMID/7878/ArticleID/784/ Migratory-Tundra-Caribou-and-Wild-Reindeer

Russell, D. E., A. M. Martell, and W. A. C. Nixon. 1993. The range ecology of the Porcupine caribou herd in Canada. Rangifer Special Issue No. 8. [online] URL: https://septentrio.uit.no/index. php/rangifer/article/view/1057/1010

Russell, D. E., D. van de Wetering, R. G. White, and K. L. Gerhart. 1996. Oil and the Porcupine Caribou Herd - Can we quantify the impacts? Rangifer 16(4):255-258. https://doi.org/10.7557/2.16.4.1252

Russell, D. E., P. H. Whitfield, J. Cai, A. Gunn, R. G. White, and K. Poole. 2013. CARMA's MERRA-based caribou range climate database. Rangifer 33(2):145-152. https://doi.org/10.7557/2.33.2.2535

Shively, K. J., A. W. Alldredge, and G. E. Phillips. 2005. Elk reproductive response to removal of calving season disturbance by humans. Journal of Wildlife Management 69:1073-1080. https://doi.org/10.2193/0022-541X(2005)069[1073:ERRTRO]2.0. $\mathrm{CO} ; 2$

Smith, W. T., and R. D. Cameron. 1985. Reactions of large groups of caribou to a pipeline corridor on the arctic coastal plain of Alaska. Arctic 38(1):53-57. https://doi.org/10.14430/arctic2107

Standlea, D. M. 2006. Oil, globalization, and the war for the arctic refuge. State University of New York Press, Albany, New York, USA.

Stankowich, T. 2008. Ungulate flight responses to human disturbance: a review and meta-analysis. Biological Conservation 141:2159-2173. https://doi.org/10.1016/j.biocon.2008.06.026

Tanus, T. 2012. Oil development in ANWR: the precautionary principle is compatible with the Fish and Wildlife Service's statutory mandate. Washington Journal of Environmental Law \& Policy 2(2). https://digitalcommons.law.uw.edu/wjelp/vol2/iss2/4

U.S. Congress. 1980. Alaska National Interest Lands Conservation Act. U.S. Public law 96-487. U.S. Congress, Washington, D.C., USA. https://doi.org/10.3133/70202593

Vistnes, I., and C. Nellemann. 2001. Avoidance of cabins, roads, and power lines by reindeer during calving. Journal of Wildlife Management 65:915-925. https://doi.org/10.2307/3803040

Vistnes, I., and C. Nellemann. 2008. The matter of spatial and temporal scales: a review of reindeer and caribou response to human activity. Polar Biology 31:399-407. https://doi. org/10.1007/s00300-007-0377-9

Wedeles, C., S. Beukema, C. and L. Greig. 2012. Evaluation of tools available for cumulative effects assessment for the Northwest Territories - literature reviews: models and management. Prepared for Government of the Northwest Territories, Department of Environment and Natural Resources Wildlife Research and Management, Wildlife Division, Yellowknife, Northwest Territories, Canada. [online] URL: https://www.wrrb.ca/sites/ default/files/Grieg_2013 GNWT_ESSA.pdf 
White, R. G., C. J. Daniel, and D. E. Russell. 2013. CARMA's integrative modeling: historical background of modeling caribou and reindeer biology relevant to development of an energy/ protein model. Rangifer 33(2):153-160. https://doi.org/10.7557/2.33.2.2536

White, R. G., D. E. Russell, and C. J. Daniel. 2014. Simulation of maintenance, growth and reproduction of caribou and reindeer as influenced by ecological aspects of nutrition, climate change and industrial development using an energy-protein model. Rangifer Special Issue No. 22. 34. https://doi.org/10.7557/2.34.2.3269

Wolfe, S. A., B. Griffith, and C. A. G. Wolfe. 2000. Response of reindeer and caribou to human activities. Polar Research 19:63-73. https://doi.org/10.1111/j.1751-8369.2000.tb00329.x 